\title{
FROM DAVENPORT TO VICKSBURG: THE ODYSSEY OF A SOLDIER IN THE CIVIL WAR
}

\author{
Edited with an Introduction \\ by Dr. James W. Pohl \\ San Marcos; Texas
}

The following are selected letters from the complete collection of Captain Jacob De Witt Brewster for the period of January 1862 to April 1865, now owned by the University of Texas. Dr. Pohl was asked by the University of Texas. Archives to edit the recently purchased Brewster letters.

Dr. Pohl was born in Dubuque, Iowa, and still has relatives there. He is presently an Associate Professor of History at Southwest Texas State University in San Marcos.

Jacob De Witt Brewster is the author of all the following letters. As the reader will quickly perceive they were largely intended for his wife; however, there is one letter to his father in this selection.

Jacob Brewster was born in Montreal, Canada on the sixth of May, 1836. Little is known of his early days but there is perhaps an indication that he may have been something of a rebellious youth as a relative reports that at the age of seven he chased his youthful stepmother and the household cook around the kitchen while brandishing a knife. It is not known when this Canadian-born man with the New England background moved to the western part of the United States, but marriage records indicate that at the time of union he was a resident of Davenport, Iowa.

He was twenty-six years old when he married Louisa Keefer of Thorold, Canada. She was two years younger than he. The nuptials took place on April 15, 1862. The marriage was a fruitful one and at least five children, four boys and a girl, were born to the couple.

Upon the outbreak of the Civil War, Jacob joined the Second Iowa Infantry: He was commissioned to a captaincy in May, 1861. By October 5 of the same year he was discharged in St. Louis, Missouri and was re-appointed to 


\section{To nll to whom these gegents ghull come,}

GNEI:\%NG :

Fhis is to Certify that the following entry was in the Roturns of Mrarriages mado to the Regintme General of the Province of Ontario, by the liegistrar of the $\div$ -

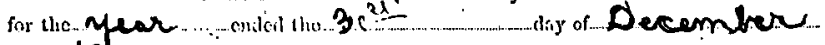
A.1. 18.69 and is now thits on reeord in the books of this Jepartment.

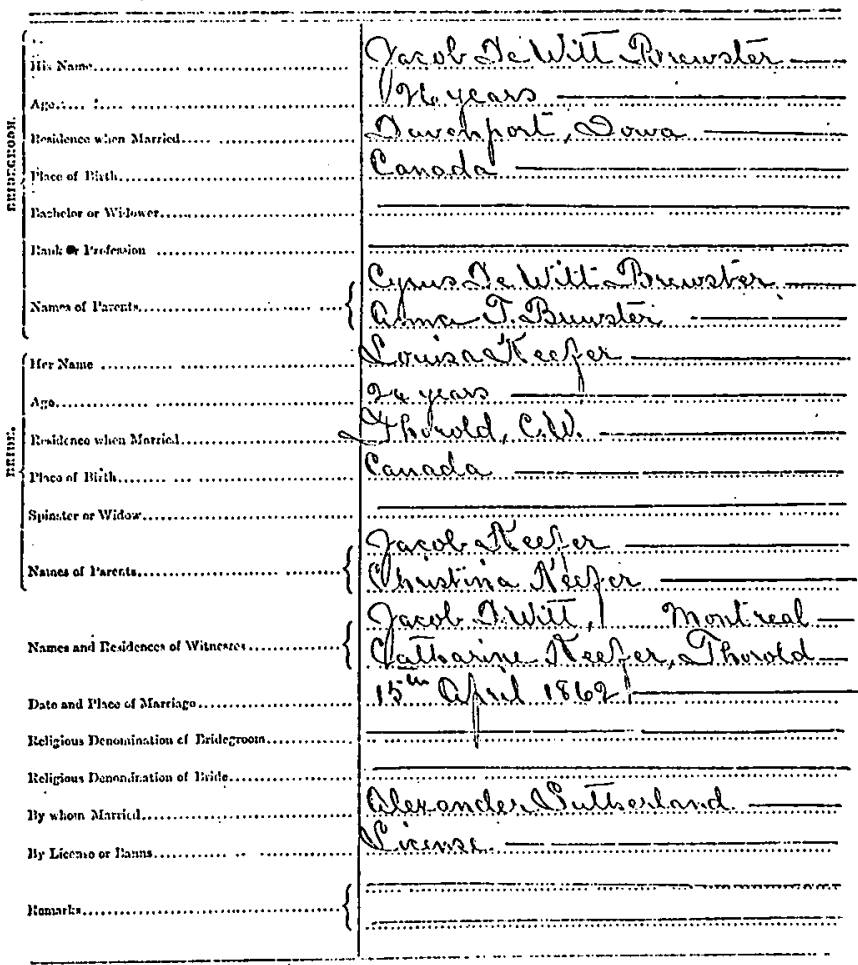

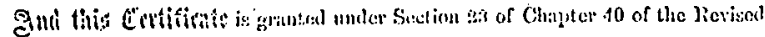

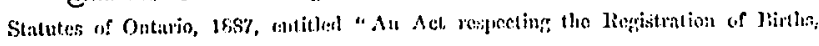
Marian, : :

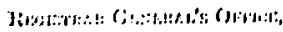

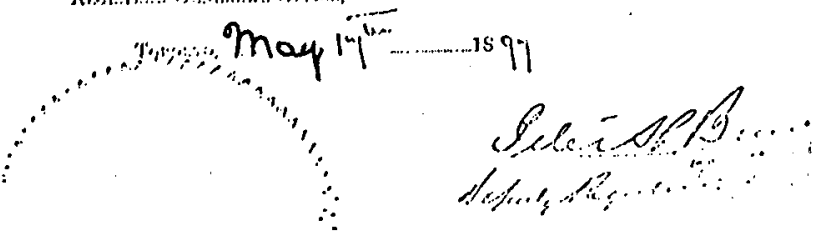


the rank of captain three days later. In this capacity, he served as aide on the staff of General Francis J. Herron. He held numerous positions, and if his self-evaluation as found in his letters may be believed, he was a trusted and competent officer. For a period, he was the ordnance officer for the Third Division, Army of the Frontier, and the chief of artillery for the extreme left division of the Army of the Tennessee at Vicksburg. He was present at or in the vicinity of many major engagements in both the West and South during the war.

On the fifth of May, 1865, he was honorably discharged and once again took up residence in Davenport. Apparently, either restlessness or opportunity caused him to shift his home again as he moved to Leavenworth, Kansas and to Derby, Connecticut. His removal to Derby was in 1869, and here he remained until he died after a four-month lingering illness on November 8,1896 . He was sixty-one. The cause for his death was cited as ascites or dropsy of the abdomen. He was survived by his wife and five children, but Louisa was to follow him just two months later. During his last years he was quite active in the Grand Army of the Republic.

Regarding the text of these letters, they appear exactly as written by Jacob Brewster. Nothing has been changed." However, if a word has been deleted by the author, the editor felt the letters would be more readable if he were to replace the deleted word with brackets. Generally speaking, the guide for editing these letters was Clarence E. Carter's Historical Editing which is printed by the Government Printing Office, and is Bulletin number seven of the National Archives. A small bibliography of all works consulted in the editing is attached. The editor found the two most useful items to be War of the Rebellion: A Compilation of the Official Records of the Union and Confederate Armies and Mark M. Boatner's The Civil War Dictionary.

James W. Pohl

${ }^{\circ}$ It was necessary to change the method of sentence spacing in the letters found on pages 506,507,510,511,513 and 514 respectively, in order to make use of all available page space.

The Eiditor 
TO FATHER (three pages of manuscript)

\section{Dear Father}

St. Louis, Mo. Jan. 28/62

Gen. ${ }^{1}$ Herron $^{1}$ \& Staff arrived here this evening and I lose no time in writing. Owing to the recent rebel raid on Springfield, ${ }^{2}$ while our army was over 100 miles south there has been a suspension of mails, as soon as Marmadukes raid was known at Fayetteville, ${ }^{3}$ our Division was sent to the East to intercept his return to Arkansas but our orders came too late, for when we reached Belville, we learnt that the rebels had pressed south 90 miles east of Nellville and the chase was given up. So much for Schofield's management. ${ }^{4}$ Still the rebels gained nothing by their trip but lost four of their best officers killed, among them Gen. Emmett M. Donald. After our chase was given up Gen. ${ }^{1}$ Curtis $^{5}$ sent to Gen. ${ }^{1}$ Herron to come here, as we arrived this

${ }^{1}$ Francis Jay Herron was actually commissioned a Brigadier General in the U.S. Volunteers on July 16,1862 . On November 29,1862 he received his Major-Generalship in the U.S. Volunteers. While still a Lieutenant Colonel in the 9th Iowa, he fought and was captured at Pea Ridge. He received the Medal of Honor for his participation in this action. Mark Mayo Boatner III, The Civil War Dictionary, pp. 397-98 (hereafter cited as Boatner).

${ }^{2}$ This refers to the raid of J. A. Marmaduke, Brigadier General, C. S. A., who attacked Springfield and after eight hours of fighting caused the withdrawal of the defending Union force of 4,200 men. Although the Northern loss was more severe than the Southern, Marmaduke did not continue the attack, but he withdrew toward Rolla, Missouri. The War of the Rebellion: a Compilation of the Official Records of the Union and Confederate Armies. Series I, Volume XXII, pp. 194-95 (hereafter cited as Official Records).

${ }^{3}$ Fayetteville is located in Washington County about twenty-two miles due east of the Oklahoma border and about thirty miles due south of the Missouri border. This means of course, that it is located in the northwestern part of the state of Arkansas.

${ }^{4} \mathrm{John}$ McAllister Schofield was appointed Brigadier General in the U.S. Volunteers on November 21, 1861. He commanded the Army of the Frontier, Department of Missouri. He was later to receive the appointment to Major General, U.S. Volunteers. He was to be breveted to the rank of Major General U.S. Army because of his action at Franklin. Years later (1892) he was to receive the Medal of Honor for his participation at Wilson's Creek. Throughout this correspondence, Jacob Brewster will speak very deprecatingly of Schofield. Boatner, pp. 726-27.

${ }^{5}$ Samuel Ryan Curtis was graduated from the U.S. Military Academy at West Point in $183 \mathrm{l}$ as an infantry officer. He served with Zach- 
evening we have not seen Gen. ${ }^{1}$ Curtis yet but from rumor I think it more than likely that we shall go to Vicksburgh. Gen. ${ }^{1}$ Herron's nomination as Major Gen. ${ }^{1}$ has gone to the Senate \& will undoubtedly be confirmed as soon as this is done, my commission is secured, so that I feel much better than I did a while ago.

Yours Affectionately, Jacob

\section{TO WIFE (five pages of manuscript)}

Head Quarters 3rd Div. Army of the Frontier

Camp Hollows, Arkansas October 29. 1862

My own dearest Wife

My last letter to you was written day before yesterday since which time the 3rd Div has had its first battle with the rebels. Just after dispatching my letter orders were recd to move against the enemy who were supposed to be encamped a little south east of Fayetteville (I have before told you that this Town is about 18 miles south of this Point) and by this programme. This entire 2 nd Div. (Gen. ${ }^{1}$ Totten $^{8}$ ) under the immediate command of $\mathrm{Gen}^{1}$ Schofield were to start from their camp (about seven miles northwest from this place) about four PM and taking the direct road to Fayetteville attack the enemy in Front. Gen. ${ }^{1}$ Herron was to take the greater portion of our cavalry and get around to the enemy's rear and effect a diversion in favor of $\mathrm{Gen}^{1}$ Totten. ${ }^{7}$ The plan being to let $\mathrm{Gen}^{1}$ Totten get the whole credit if possible, another Missouri State Militia dodge. Our

ary Taylor in the Mexican War and later served as Republican Congressman from Iowa. In May of 1861 , he became a Brigadier General in the U.S. Volunteers. He was the victor at Pea Ridge, and, shortly thereafter, he was promoted to Major General, U.S. Volunteers. Boatner, p. 215.

${ }^{6}$ Joseph G. Totten was a graduate of the U.S. Military Academy in 1805, and he had served in the War of 1812. He died a breveted Major General in April 22, 1864. Boatner, p. 843.

${ }^{7}$ On October 27, 1862, Schofield notified Blunt of his intention to secure Fayetteville with the support of Totten's division. He requested that Blunt follow in support of the operation. On the same day, he also requested that Herron move against the enemy's rear as Brewster accurately relates. Schofield ordered Herron to fall back and join him if he found the enemy in large force. Official Records, Series I, volume XII, p. 766 . 
orders were not recd until nine in the evening when a large portion and the best armed of our cavalry were out on picket duty and scouting however the Gen ${ }^{1}$ gathered together what were in Camp in all less than one thousand men and with a portion of his staff (Capts Clark \& Myself Lieuts Rapell \& Siras) started at ten PM five miles from here we left the road and struck through the "brush" by Cow Paths etc: and you can not well imagine the time we had getting through in the dark, after a while we got into a better road and about four oclock in the morning we ran into the rebel Picket, we were riding in front with the advance and so dark in the woods that we could hardly distinguish the horseman directly in front when all at once we heard the Cmd Halt when involuntarily we all stopped, Drive in the picket called the General and the next instant came the sharp click of the Hammer and report of the Rifle, to which our men at once replied, this lasted about five minutes, not a very long period of time in itself but long enough for our satisfaction for the balls whistled uncomfortably close to our ears. Fortunately no one was hurt on our side and the Pickets left. The country was entirely new to us and we did not know how near we might be to the rebel camp nor what their force was, so the General ordered a halt to wait for daylight, taking the necessary steps to avoid a surprise on our side we laid down on the ground with our bridles in our hands and took a short sleep. as soon as there was sufficient light to see the road we made a new start but this time in regular line of battle, first went the line of skirmishers or Flankers extending about one quarter mile on each side of the road, next the advance Guard of four companies, about two hundred yards back of these the Gen. ${ }^{1}$, Staff and body Guard (of one company) about five hundred yards in our rear the main column. In this manner we passed some two miles before any alarm then we met the skirmishers of the enemy who at once exchanged shots with our men who steadily advanced the' rebels falling back to their camp we soon took one of them prisoner and at first he would say nothing but we soon found a way to make him speak and then learnt that their camp was about two miles distant, the force consisted of five Regi- 
ments of Texas Rangers with one Battery by this time we had had several horses killed and several men wounded we kept steadily along meeting more and more opposition until within about one quarter mile of their camp where a turn in the Hills showed their force drawn up in Line to receive us, by this time repeated additions had been made to the advance Guard so that it included half of our whole force, now the (sic) was ordered out but the whole force was maneuvered as light skirmishers as we were too small a force to attack in Line then came the heat of the engagement. All this time, about three hours, we had been anxiously listening for the sound of Gen ${ }^{1}$ Tottens Division but no sound came and $\mathrm{Gen}^{1}$ Herron begun to feel blue when the rebels gave way. You should have heard the shouts of our men, we at once drove them through their camp and then came the pursuit. Up to this time the Staff Officers had had but little to do that day in the dangerous line but now came our turn, riding directly to the front with orders to the Battalion Commanders - however, we escaped unhurt They had no tents but cut Branches for Booths in the place of them. It was a complete surprise to the Rebels for we found Dough in pans just ready to bake and I saw a slice of Beef partly cut off \& the knife still in it about twenty minutes after we gained their camp we learned that Gen Hindman $^{8}$ with fifteen thousand rebels were only six miles off on their way to meet us, so the Gen ${ }^{1}$ thought we had better leave in our turn especially as we had not heard a word from Gen Totten and could not tell why he had not come up as ordered. After taking just time enough to destroy all their camp utensils etc we started for Fayetteville twelve miles west of us. In riding over the field I saw some twenty bodies of dead rebels but we had no means of ascertaining how many men were the total killed for we could not stay to collect them for burial leaving that duty for Gen Hindman. We had

${ }^{8}$ Thomas Carmichael Hindman, after fighting in the Mexican War, became a lawyer and entered politics. He was elected to Congress as a representative, and being an ardent secessionist was appointed to the rank of brigadier general in the Confederate Army. He was in command of a division at Shiloh and fought Curtis at Prairie Grove. Later battles in which he participated were Chickamauga, Chattanooga, and Atlanta. Boatner, p. 402 . 
none killed outright but several severely wounded. So much for our fight of about one thousand ag't 5000 \& a battery ${ }^{\circ}$. for we had no artillery with us. About two miles from Fayetteville we met Gen $^{1}$ Schofield marching out to the attack so much for a Militia Gen'. He was astonished.

to find what we had done and he could not understand how Gen' Herron attacked such a force at all \& still more to fight them for four hours and finally clean them out. We entered Fayetteville about $3 \mathrm{PM}$ and halted two hours to feed the animals \& get something to eat ourselves, the first food we had since supper the day before, at five we started for this place arriving at ten in the evening, having been gone just twenty four hours and marched fifty four miles which with the four hours fight made a good days work and we had no trouble in going to sleep - in fact - I slept on my horse part of the time. On reaching home we found that a party of Bushwhackers ${ }^{10}$ had attacked one of our Army wagons some three miles from camp and killed one man and wounded another, they then killed the mules (six) and burnt the wagon. This was a portion of a foraging party sent out for food for the animals and not keeping close up was captured We got very good evidence that the people in the vicinity were accessories if not principals in the murder so the $\mathrm{Gen}^{1}$ sent down today and had four of them hung \& their houses etc burned and given orders for the same retaliation for the future which I think a good warning and will prevent repetitions of such outrages. Nearly all the people in this vicinity are entirely rebel and show it plainly. We have observed in various families today strange manifestations so we expect to be attacked here tonight and have increased our pickets to prevent a surprise - We know of one considerable force that moved this way last night but that we can

${ }^{9}$ It is difficult to ascertain the size of the units involved or the loses; however, apparently the victory was something of an accomplishment as General Curtis telegraphed compliments to Herron. Official Records, Series I, Volume XIII, p. 768.

${ }^{10}$ This term was originally applied to any of a wide variety of backwoodsmen. At the time of the American Civil War, it specifically referred to Confederate guerillas. Boatner, p. 109. 
readily handle, what additions may be made we do not know so that it becomes us to "go slow". Today brought me yours of the 21st also a letter from Clinton I can not answer yours today but the letter is good enough to keep and I shall want to write again in a day or two Remember me to all and for yourself my dearest wife I reserve all love, trusting in your happiness at all times and that we may meet again in safety. I forgot to say that Gen ${ }^{1}$ Tottens gave excuse for being late was that he could not find the rebel camp sooner, our Gen ${ }^{1}$ found it.

I close as ever

Your affectionate husband Jacob

TO WIFE (four pages of manuscript)

Headquarters Second \& 3rd Divisions Army of the Frontier Camp at Praire Grove, Arkansas Dec. 9th 1862

My dearest Wife

I have to write this in pencil for all our desks are in use \& I want to send this by first mail, I wrote to you just before we left Camp Curtis we are now in camp about 12 miles SW from Fayetteville having just got thro' one of the severest battles of the war. I told you I should go thro all safe and so it is. Neither Gen ${ }^{1}$ or Staff were injured - but to commence at the beginning. Day before yesterday we were marching down from Fayetteville the $\mathrm{Gen}^{1}$ \& Staff with the escort were as usual in the advance except in this case two companies of cavalry as advance Guard were a quarter mile before us Gen Blunt cmdg 1st. Div Army of the Frontier was at Cane Hill ${ }^{11}$ about ten miles SW from here and on moving down to help him not expecting to meet any enemy before we reached Blunt. We passed thro' Fayetteville at day light and soon after heard the cannon at Cane Hill. The day previous we had sent the most of our cavalry, nearly 3000 ahead of us \& supposed they were with Blunt but it seems

"As Brewster indicates Cane Hill is ronghly ten miles southwest of Prairie Grove. Today it is a small community of approximately 50 persons, and it has changed its spelling to Canehill. 
some of them stopped to Feed, just about this point. The Rebels heard of our coming and attacked Blunt just before day light but it seems that this was a feint for they only sent a small part of their force agt him which he soon beat off,. in the meantime they moved their main body around to this side and came after us. The first Federal they met were our cavalry who were attacked by 10,000 Rebels and after a short fight our men had to run back, half a mile from the fight they ran into our advance of 2 companies, the Major cmdg these last is an Old Soldier and did his best to stop the runaways but of no use, they were panic struck and Major was obligated to let them pass him, he drew his own men up in line of battle \& waited the attack but was soon surrounded on three sides and his men had to run but the Major \& nine men were captured \& we do not know how many men killed, the rest of his men took to the brush and ran all the rest of the day getting back to us. In the meantime we heard the firing but supposed it was Blunt at Cane Hill. The first thing we knew was the advance of our cavalry rushing upon us in the wildest confusion. The gen ${ }^{1}$ at once threw his escort across the road to stop the fugitives. We all set in but it was no use they were too badly frightened, The Gen ${ }^{1}$ shot one man which checked them but a moment after a number more came in sight shouting etc \& we had to let them go for the credit of our army I may add that this was a Regiment of Arkansas Troops sent in from Pea Ridge. When the Gen ${ }^{1}$ saw it was no use to attempt to Rally the Arkansas Troops he sent me to hurry up a Reg of Infantry and a Battery and get them in position while he arranged the balance of the command When the advance of the Rebels came in sight of my men they stopped for a short while. pretty soon 3 Regiments deployed in line of battle and again started, We sent a lot of shell into them when they ran, we advanced and drove them to this point, about two miles. Here their whole force was posted on a high hill between us and a valley one quarter mile wide then a creek and where the road crossed the creek considerable Brush but another range of hills beyond this, as soon as we had crossed the creek and emerged from the Brush they began to Shell us 
\& we fell back across the creek to reconnoiter, here we had a pause of about an hour - during this time the $\mathrm{Gen}^{1}$ and Staff rode about on each side of the creek, found how the country was situated \& decided how to dispose of the troops, then we got all into position when the first thing the rebels knew we commenced to shell them from 18 Rifled Guns, ${ }^{12}$ they replied quite strong at first but our men soon silenced their batteries, they then changed position of their Guns but could not fire more than 3 or 4 shots before we stopped them the battle commenced in earnest about 1 P.M. and lasted until after dark when the rebels left. About 4 P.M. our men began to show signs of fatigue, they had marched 120 miles in 3 days, had no sleep for 2 nights and nothing to eat since the afternoon before the fight, we began to feel blue, when we heard firing on our right which we knew was not our men and soon learnt that Blunt had sent help to us. This rallied our men when they made a desperate charge and cleared the field before us but Blunts men had to fight nearly an hour afterward. The next (yesterday) morning the only rebels to be seen were the burial parties with their flag of truce soon after a flag of Truce came in saying that Gen ${ }^{1}$ Hindman \& Marmaduke Cmdg the Rebels desired a conference with our Generals. This was granted \& Gen Blunt \& Herron with Staffs \& Escorts went over to the later Head Quarters of the Rebel Genls, here we had a long interview with the latter, relative to exchange of Prisoners the care of the Sick the burial of the dead after which the Rebel Gents left for the sunny South, leaving us in full possession of the field then we learnt that with 6000 men for most of our Cavalry were with Blunt \& we had to leave a strong force to guard our large Train at Fayetteville, we had fought 28,000 Rebels from ten AM until dark in their own chosen position and whipped them badly. They say they

${ }^{12}$ Often this term is misleading. The word "gun" is often used in this correspondence to describe any weapon, small arm or larger. Technically speaking, a gun is a cannon. From this term, the editor assumes that a rifled gun is a cimnon with a bore constructed with lands and grooves so to improve its accuracy. The caliber cannot be determined from the text, but the editor assumes the piece is rather large. Boatner, p. 364. 
had 800 killed in the field but we suppose they lost nearly double that, cant say yet the number of their wounded, we have not ascertained the number of our killed, but suppose it will be over 500 . We Know they had one General, 3 Colonels, 2 Majors and a large number of company. officers killed. We lost 1 Lieut. Col. killed and a good many company officers (Capt \& Lieuts) killed, can not say yet how many are wounded - one of our Regts lost 60 killed that they know of \& suppose there are still more, we do not know how many we lost in total killed but will find out probably today - It was a desperate on both sides and all our men fought splendidly -one Inf Regt. the 94th Ills $^{13}$, fought 10 Rebel Regts for half an hour, they were almost beaten when I got the 26th Indiana $^{14}$ to help them when the Rebels ran like a flock of sheep I have no time to describe all the different occurrences but they will keep. I have a number of trophies which I will keep also we had a great many narrow escapes but our party are all uninjured. The Major captured in the morning was released last night on Parole \& is now with us, I expect to start with a flag of truce for Fort Smith ${ }^{15}$ tomorrow to exchange the Major and some other prisoner. I must stop this now but will try to write again in a very few days, if I go to Fort Smith I shall be []$^{10}$ last night, they

${ }^{13}$ At this battle, the 94 th Illinois was composed almost entirely of new men. In the words of their brigade commander, Colonel William W. Orme: "The Ninety-fourth Illinois behaved well. The safety of our left wing depended in a great measure upon their efforts. They withstood every attack on our left, and repulsed the enemy with heavy loss." Official Records, Series I, Volume XXII, p. 131. However, probably the heaviest fighting was engaged in by the Nineteenth Iowa. This regiment lost more than any other Union force at this engagement but rallied well and helped carry the day. Official Records, Series I, Volume XXII, p. 131. The aggregate loss for this unit was 103 officers and men killed or wounded. Official Records, Series I, Volume XXII, p. 86.

${ }^{14}$ The Twenty-sixth Indiana in the words of Herron "fought nobly." Official Records, Series I, Volume XXII, p. 102. When the Nineteenth Iowa had been driven away from captured Confederate guns by superior forces, the Thirty-seventh Illinois and the Twenty-sixth Indiana charged and retook possession. Official Records, Series I, Volume XXII, p. 101.

${ }^{15}$ Fort Smith is located in Sebastian County in the far western part of Arkansas only one mile away from Oklahomia. It is on the Arkansals River and only six miles southwest of Van Buren.

${ }^{16}$ Entire line of letter illegible. It is torn and the light penciling is completely rubbed out. 
are in a dreadful hurry- he shall follow them as soon as our men are rested a little, but the contest was so unequal that are men are almost prostrated. The rebels had 15,000 more men than they brot into the field they kept these to fight Blunt supposing he would come straight to our help instead of which he took a short circuit lucky for us for our hands were full without them.

Give my love to all the family and with the fondest love for you my own dearest wife, I am as ever

I send you a little Confederate Money

Yours Truly - Jacob

TO WIFE (two pages of manuscript)

Head Quarters, Army of the Frontier

On Board Steamer White Cloud, en route to Vicksburg, Miss.

My dear Wife

June 5th, 1863

You may wonder what is meant by the above date and to relieve "womanly" curiosity I begin this with the explanation. Our General has succeeded in getting not only himself but the Major part of our Army out of the hands of the Philistines, ie Governor Gamble ${ }^{17}$ and his Fool Schofield. ${ }^{18}$ To the great disgust of those Wretches and to our great delight an order was procured from the War Dept for us to proceed forthwith to reinforce General Grant. Our Fleet with about twelve thousand men and four Batteries is now on the way and we expect to reach Cairo early tomorrow morning and to be in front of Vicksburg Monday night, we hope to get there in time to share in the capture

${ }^{17}$ Hamilton Rowan Gamble was born in Virginia and educated at Hampton Sidney, but he removed to Missouri where he was a lawyer, the state Secretary of State, a judge, and a member of the legislature. $\mathrm{He}$ was the Provisional Governor in 1861 but he was not an ardent Unionist. Rather, he hoped that the strife of the state could be settled by compromise. He was opposed to the president's first call for troops, yet he led the Missouri militia in an anti-guerrilla campaign. Boatner, p. 322 .

${ }^{18}$ Brewster makes several derogatory comments about General Schofield, and in one spot mentions his "clique." Apparently, there was some friction within the army on this point. On May, 1, 1862, President Lincoln wrote to Major-General Halleck: 
of that little Town and we shall probably be allowed the honor to lead the assault, then as Kittie would say, "look out for glory". We have the choice of the troops from the Dept. of the Mo. and consequently a very fine organization, every one is full of enthusiasm and several "Southern Confederacies" must fall. I with rest of the Staff, am very busy and have every moment occupied with duty but I send these few lines to notify you of the change and if I can, as no doubt I will, I will write you a letter before we reach the Scene before us. If you are writing to Montreal please advise them of my change of address to Care of Maj Genl Herron near Vicksburg Miss via Cairo and Memphis, leaving out Army of the Frontier until we know what name may be given us. I suppose we shall be designated some army corps as our old "A of $F^{\prime \prime 19}$ is now broken up. I must bring this to a close repeating my promise to write you more fully in a day or two. You will consider this a Telegraphic Message. You may possible see no mention of this movement in the Newspapers for such publication is contraband as it might reach the enemy sooner than we can \& have them know it.

Once more my dear Wife I would send you all love and every kind wish from

Your affectionate husband-Jacob

"I am pressed by the Missouri members of Congress to give General Schofield independent command in Missouri. They insist that for want of this their local troubles grow gradually worse. I have forborne, so far, for fear of interfering with and embarrassing your operations. Please answer, telling me whether anything, and what I can do for them without injuriously interfering with you."

Halleck frankly replied:

"General Schofield has entire command of the Missouri Militia in the United States service, and of the volunteers in two-thirds of the State. $\mathrm{He}$ has been informed that his district will comprise the entire State as soon as Major-General Curtis moves south. This is more than his rank entitles him to. If he is intriguing for more he is not honest. I would rather resign than to have him given an independent command in my department. I have yielded much to the importunities of his friends, but they ask still more." Official Records, Scries I, volume XIII, page 368 .

${ }^{19}$ This is Brewster's designation of the Army of the Frontier. Nowhere else has the editor been able to find the designation employed. 
TO WIFE (two pages of manuscript)

Head Quarters, Army of the Frontier, below Fort Pillow ${ }^{20}$ 9 P.M. Steamer White Cloud, June 7th 1863.

My dear Wife

I wrote you a few lines to mail at Cairo and intend to mail this at Memphis which place we hope to reach by midnight. We are getting along very well, most of our boats reached Cairo before we left and I. suppose they are not far behind us now. At Cairo we met the advance of Gen'l Burnsides old $^{21}$ Division which is going to Vicksburgh. We have got the start of other reinforcements and shall probably win the credit for being the first to report to Gen'l Grant. Our Boat has just stopped to "wood up" ${ }^{22}$ and I had to lay aside my writing to post a picket ashore to prevent a surprise by Guerrilas. The owner of the Wood Yard tells us that today

${ }^{20} \mathrm{In}$ Tennessee, this fort is probably best remembered for the Fort pillow "Massacre" in which a division of Confederate Cavalry under Brigadier-General James $R$. Chalmers attacked the position held by 557 Union troops almost equally divided into Negro and white. On the twelfth of April, 1864, General Nathan Bedford Forrestt arrived to take command of the Southern attackers. Although the Southern contingent maintained that heavy Union losses were the result of the battle itself, the Committee on the Conduct of War came to the conclusion that the heavy Northern loss (almost the entire garrison was the casualty figure) was a result of atrocities of the most barbarous nature which occurred after the garrison's capture. Boatner, pp. 295-96.

${ }^{21}$ Ambrose Everett Burnside graduated from the United States Military Academy in 1847; however, he did serve in both the Mexican and Indian Wars. He resigned his commission to become a weapons manufacturer in 1853; however, upon the outbreak of hostilities he returned to the Army as a colonel in the First Rhode Island Volunteers. He was promoted to the rank of Major General and turned down an offer to command the Army of the Potomac on two separate occasions. His career was dotted with misfortune which usually was the result of his inadequate handling of troops, viz.: Antietam, Fredericksburg, and Petersburg. After the war he returned to public life where he was both governor of and senator from Rhode Island. Boatner, p. 1.07.

Herron's unit actually beat Burnside to Grant's headquarters at Vicksburg. The Burnside troops were members of the Ninth Corps. Official Record, Series I, volume XXVI, part 1, pp. 42-44.

${ }^{22}$ Despite the fact that John H. Morrison in his excellent History of American Steam. Navigation mentions the use of coal as fuel in western waters as early as 1809 , wood was apparently used for the purpose of the White Cloud. John Morrison, History of American Steam Navigation, p. 191. 
there was a force of these Guerillas Seven Miles below this point. and we are expecting them to favor us with a few shot in passing. We have on this the flag ship a small Infantry Guard and our Rifled Cannon ${ }^{23}$ to return such favors. It will be very exciting below Memphis for those scoundrels are quite numerous and will keep us awake. At Cairo I found yours with the Neck Tie and that of the 2nd. both were a surprise for I did not hope for a letter let alone two so soon but the Mails come from St. Louis to Cairo by Rail and so beat the Steamers. Tell our Cousin Mary that her handiwork is very pretty and shall be taken care of, on state occasions I will do style with it. We have got into very hot weather, Linen Coats, Musquitoes and Black Berries and still further down we may find it warmer. At Cairo last night we recd the latest news, Johnston ${ }^{24}$ is massing a very large force of Rebels in the rear of Grant and there is little doubt that you will soon hear of the greatest Battle if not the Battle of the War. ${ }^{25}$ If our reinforcements get in soon enough there should be no fear for the result. Burnsides men from the Army of the Potomac will take part in a Western fight and see how they like our way. This move delays my money matters so that I can not enclose in this what I had hoped to send you but I expect that I shall be able to do so when the fight is decided. Should our General be given command of an "Army Corps", it may help me considerable, if not,

${ }^{23}$ See footnote 12 .

${ }^{24}$ Joseph E. Johnston was born in Virginia, and he was one of the foremost generals of the Confederacy. A graduate of the U.S. Military Academy in 1829, he served in the Black Hawk Indian War and the Mexican War as well. Much of his Civil War career was marked by hostility with Jefferson Davis. Boatner, p. 441.

The general was indeed moving troops in the direction of the Big Black River, but Brewster did not know, nor did Grant entirely, that Johnston was not keen on attacking the investing force. However, Johnston notified Richmond by telegraph:

"I cannot advise as to the points from which troops can best be taken, having no means of knowing. Nor is it for me to judge which is best to hold, Mississippi or Tennessee-that is for the Government to determine. Without some great blunder of the enemy, we cannot hold both ... I consider saving Vicksburg hopeless." Joseph E..Johnston, Narrative of Military Operations, p. 199.

${ }^{25}$ There was little doubt indeed. She had her choice between Gettysburg July $1-3$ or Vicksburg, July 4. 
my expectations of the past few days will probably remain as if we had continued to be in the Army of the Frontier. I am in tolerable good spirits and look forward to the next few days with all interest. we shall pass through great events and take part in them. I would like to have more time so as to write you a better letter but have to hurry so that I may resume my reports. If anything of interest occurs you will see it at once in the news papers and as soon as the fate of Vicksburgh is decided I intend to write you full accounts of what I see and hear of. Till then my dear Wife, remember me kindly to all friends and receive all love and kind wishes for yourself from

Your affectionate husband Jacob

If you write to Sarah as you propose you will probably tell them where I am going to for I have not written but in writing you need not know this last fact.

\section{TO WIFE (three pages of manuscript)}

Headquarters, Army of the Frontier, Camp at Vicksburgh, Miss. June 13th My dear Wife.

I wrote you advising you of our late movement from Rolla and mailed the letter at Cairo and on the way down I mailed another short letter at Memphis, since then I have had about all I could attend to but now, although very tired, I can not delay writing any longer, We met with no trouble coming down. at one place the Guerillas tried to decoy us into landing but we "couldn't see it'. We were first sent up the Yazoo River ${ }^{26}$ to Chickasaw Bayou, the spot where our men were so badly whipped and forced to retreat from. ${ }^{27}$ This is now the general Base of operations or perhaps you may understand better if $I$ add it is the Landing Place for

${ }^{26}$ This is a navigable river in Mississippi, and it runs in a southwesterly direction. It runs approximately 188 miles until it empties into the Mississippi eleven miles above Vicksburg.

${ }^{27}$ This was a bruising defeat for the North. Union losses: killed, 208; wounded, 1005; missing, 563; total 1776. The Confederate losses: killed, 63; wounded, 134; missing, 10; total, 207. Thomas L. Livermore, Numbers and Losses in the Civil War in America: 1865. pp. 96-97. 
most of the provisions and army stores, As soon as we arrived the General \& Staff got out their horses and rode over to General Grant's Head Quarters, these are opposite the center of the enemy's works and about half a mile from them. The Tents are pitched on a ridge in the woods commanded by one of the Rebel Forts whose Guns are kept quiet by our sharp shooters. The Tents are concealed from the rebel view by the Trees. Genl Grant sent us back to our boat and down the Yazoo to the west bank of the Mississippi just above and in full view of the City. This place is known as Youngs Point or Shermans Landing, as we reached there about Sundown we did not attempt to land until the next morning. A short distance below us lay Porter's Fleet ${ }^{28}$ of Mortar boats and we had a fine view of them as they were shelling the Town and the rebel Forts, in the night the sight is grand. The next day we marched across the point and again made th river below Vicksburgh and recrossed to this side landing Warrenton The Federal Troops now encircle the. City from the River above to the same below and our troops hold the extreme left or lower portion of the lines with a front of two and one half miles.

Our Head Quarters where I am now writing are situated one mile from the Rebel line of Forts and about two miles from the center of the City in a direct line. The average distance of our lines from the enemy is 800 yards and in some places not half that distance. Upon the right or upper end of the lines in one place our earth works are only forty yards from the rebel Forts but neither side can use their Cannon as the sharp shooters would pick off the Gunners before they can load. There is more or less of a cannonade and musket firing all along the line kept up all the time day and night and I can not describe the noise. It is hard to tell how long the rebels can hold out but we are closing towards them steadily and the crisis can not be very far off. It is almost useless to describe the several positions of the two armies for a person would hardly believe the facts unless he saw them. There is no danger of any rebel force coming

${ }^{28}$ This is the Mississippi scjuadron Admiral D. D. Porter. Official Records, Series I, volume XXIV, part 1, p. 46. 
upon our rear, we have force enough on the Black River ${ }^{20}$ to prevent 100.000 from crossing and if they should cross they could not advance five miles towards us by any possibility. It seems rather strange to change climates so suddenly. Here we have plenty of ripe plums and Black Berries and in another month there will be quantities of ripe Figs. This is indeed the sunny South. The weather is very warm but not enough to trouble us, I wish you could see the groves of Magnolias now in full bloom. The day before we reached Millikens Bend ${ }^{30}$ on our way down they had quite a fight there, the rebels under General $\mathrm{McCulloch}^{31}$ nephew of the old sinner killed at Pea Ridge, ${ }^{32}$ attacked a couple of Negro regiments, ${ }^{33}$ the fight was desperate but the blacks routed the enemy killing their General. The Blacks fought fully as well as any white Troops could have done and all praise is given them. ${ }^{34}$ We got our Troops into position to-

${ }^{29}$ This is also known as the Big Black. Its source is in southeastern Missouri and it converges with the White River about forty miles south of Batesville, Arkansas.

${ }^{30}$ During the Vicksburg campaign, the Confederates made an unsuccessful attack on both Millikens Bend and Lake Providence, although the Union force lost 652 men dead, wounded, or missing. Official Records, Series I, volume XXIV, part 1, p. 7.

${ }^{31}$ Henry Eustace McCulloch was born in Tennssee, but after migrating to Texas, became a sheriff and a member of the legislature as well as serving as a captain of Texas Rangers. Upon the outbreak of hostilities, he was commissioned a colonel of the First Texas Mounted Rifles and in this capacity was designated the Commander of the Department of Texas. On March 14, 1862, he received the rank of Brigadier General in the CSA and as such participated in the Battle of Vicksburg and the action at Millikens Bend. During the final phases of the war, he commanded a brigade in North Texas. Boatner, p. 530.

${ }^{32}$ This is Ben McCulloch. Although Brewster represents this man as the uncle of H. E. McCulloch, he was actually his brother. In May of 1861, he was commissioned a Brigadier General in the CSA and participated in the actions at Wilson's Creek where he commanded the Southern troops. As Brewster relates, he was killed at Pea Ridge, the victim of a sharpshooter's accuracy. Boatner, p. 530 .

${ }^{33}$ Among the Negro regimental participants were Mississippi's First Regiment Infantry (African Descent) which also served in the siege of Vicksburg. On March 11, 1864, it was redesignated the 5lst U.S. Colored Troops. Frederick Henry Dyer, (hereafter cited as Dyer), A Compendium of the War of the Rebellion, Vol. III, p. 1344.

The First Colored Heavy Artillery of Mississippi was also present. Dyer, II, 747. 
day and tomorrow shall commence our share of the work. I think we shall earn our portion of the credit I have been at work all day and have to start out early in the morning which requires that I should stop writing and get some sleep. I may not have a chance to forward this tomorrow so that I will not close it now. In a day or two we shall be able to perfect our mail arrangements so as to receive and forward our letters regularly. until this is done we have to improve chance messengers-16th. A messenger is about ready to start for Chickasaw Bayou and I must close this hurriedly. The only news this AM is that our Troops have advanced our lines at this end about 400 yards and in several places we are close up to the Rebel Works. As the name for our army is not yet announced my letters should be addressed care of Maj Genl Herron Vicksburgh Miss - In the Field -I will keep you fully informed of what is doing here and must leave it to you to inform my other friends, my time is so limited. Remember me kindly to all and for yourself my own dear Wife accept all love and good wishes from

Your Affectionate Husband Jacob.

\section{TO WIFE (four pages of manuscript)}

Head Qtrs. Left Div. Army of the Tennessee

Camp near Vicksburg, Miss. July 3rd 1863

My own dear Wife

I will write you one more letter before we take Vicksburg and will commence by telling you the plans by which we

Also present was the Louisiana Eleventh Infantry (African Descent) which served on garrison duty at Vicksburg. It was redesignated the 49th U.S. Colored Troops on March 11, 1864. Dyer, III, 1215.

${ }^{34}$ In a communication to Secretary of War Stanton, General Halleck attested to the courage of the Negro troops in the following words:

'It is represented that the colored troops in these desperate engagements fought with great bravery. . .'

Official Records, Series I, volume XXIV, part 1, p. 7 .

C. A. Dana in a dispatch to Sec. Stanton reaffirmed this by stating:

"I am happy to report that the sentiment of this army with regard to the employment of negro troops has been revolutionized by the bravery of the blacks in the recent battle of Milliken's Bend. Prominent officers, who used to sneer at the idea, are now heartily in favor of it." Official Records, Series I, volume XXIV, part 1, p. 106. 
propose to settle this matter since I wrote you last our lines have been steadily drawn closer and we have mounted a large number of heavy guns in addition to those used in our last general bombardment. ${ }^{35}$ Every gun will open tomorrow at daylight and unless the place surrenders the fire will be kept up without intermission day and night, the next morning the troops will be moved forward and storm the Town. Our Cannonade will be terrific and general opinion says will force the rebels to surrender. We are desirous to avoid storming their works if possible for our men will be so exasperated that we shall not be able to control them and prevent them from sacking the town. 11 P.M. This morning my writing was suddenly stopped by news from the Front. The enemy in front of the Division next to us had displayed white flags all along their line while both Federals and rebels had met together and were having quite a talk. I was sent to our front with orders as soon as the rebels should show a white flag in front of us, to immediately advance our Regiments and occupy their works. When I reached the front, to my surprise I found that our men had followed the Example given on their right and that both sides were in full communion. I rode at once to the nearest rebel Fort and enquired for the Cmd'g Officer. Col Young of the 43rd Georgia presented himself and in reply to enquiry said he could not explain the movement further than he had orders to cease firing at 8 o'clock this morning as a flag of Truce would be sent at that hour to Gen'l Grant. I informed him that we knew nothing of any flag of Truce and construed the proceedings of his men to mean a surrender and should at once move up our Troops to occupy his Forts. he answered again that he could not explain any further but asked reasonable time to notify his men that we would close their proceedings. He at once ordered his men to return to duty and I gave the same command to ours. While our Regiments were moving up an order came from Genl Grant stating that he was

${ }^{35}$ In a communication to Secretary Stanton, C. A. Dana reported:

"I was at Herron's lines yesterday. He has pushed them forward with much energy. His rifle-pits extend within 150 yards of the enemy, and his batteries are well advanced." Official Records, Series I, volume XXIV, part 1, p. 107. 
then considering a proposed capitulation pending which no offensive movements should be made. ${ }^{36}$. Of course our brilliant charge was not made and every thing is in uncertainty as to what will be done altho' we have little doubt but our national salute tomorrow will be fired with blank charges. All communication between pickets has been stopped also all firing. The stillness of the night is really strange to us who, before today, have scarcely seen ten minutes without the noise of Artillery. About an hour since the General recd a Telegraph from Genl Grant saying the enemy might attempt a sortie with the hope to escape and for us to unusually vigilant. Our Troops are all lying on their Arms ready for any emergency. Part of the Staff including myself are to remain up we have our horses saddled ready and it will not be easy to surprise us. I think we shall celebrate tomorrow in Vicksburg without any more fighting but we must not be too sure. The rebels have been eating mules the past four days so they are most starved out. ${ }^{37}$ Since I wrote you last I have yours of the 16th also letter from Clinton and one from Father. The latter I enclose and would request you to take care of it as I may want it in the future. You see that I did not write first but I have answered this. Clinton writes that "Kittie \& $\mathrm{Co}$ " had started for Thorold. ${ }^{38}$ I feel pretty tired and very little like writing and shall not finish this until tomorrow as it can not go any sooner. We have heard of the movements East up to the rumored fight going on near Harrisburg and of the removal of Hooker ${ }^{39}$ and

${ }^{36}$ Grant had received a letter from the commander of the Southern force, Pemberton, at ten o'clock in the morning of this dav, asking for terms of surrender. U.S. Grant, Personal Memoirs, I, 565. (Hereafter cited as Grant)

${ }^{37}$ To this assertion Grant attests: "The enemy had been suffering, particularly towards the last." Grant, I, 564 .

${ }^{38}$ Thorold, Canada. Louisa's hometown.

${ }^{39}$ Joseph Hooker, nicknamed "Fighting Joe," was a graduate of the United States Military Academy and served in the Seminole War and the Mexican War. By 1853, Hooker laid aside the sword to pursue the occupation of farming in the West. He still retained the rank of Colonel in the California Militia. Upon the beginning of the Civil War, he attempted several times to enter the Union Army. His advances were rejected by the War Department, and this action probably had its seed in an earlier feud which he had with General Halleck. He was 
Mead's appointment. ${ }^{40}$ The Army of the Potomac seems fated. I wish my dear Wife, that I was with you tonight, however I hope to have my wish gratified some day. Should Vicksburgh surrender we shall probably remain here but few days longer. Can not say which way we shall go but probably return to Missouri for we learn that Price has crossed the State Line and is moving towards St. Louis, the federal Troops retiring before him. I daresay Genl Schofield is terrified so he can not sleep. Price is moving up the same way that Marmaduke took in May when Ceneral Vandever ${ }^{41}$ drove him back. We have no fears that Price will reach St. Louis but Schofield must have some outside help, in other words he must have some one more than his clique to handle his Troops or they will be whipped sure. July 4th. 6 PM. Vicksburg is ours, was surrendered to us at ten oclock this AM with entire garrison etc. There is as yet no list of what we have gained as all day has been occupied in moving into

finally commissioned a Brigadier General in the U.S. Volunteers and participated in the fighting at Fair Oaks, Malvern Hill, and Second Bull Run. He was promoted to Major General in the Volunteers, and in this capacity was wounded at Antietam. He was commissioned a Brigadier General in the U.S. Army and :was given command of the Army of the Potomac. After his subsequent defeat at Chancellorsville, his command devolved upon General Meade. Hooker continued in the army and later actions found him at Lookout Mountain, Missionary Ridge, Cassville, and Atlanta. Boatner, p. 409.

${ }^{40}$ George Gordon Meade (misspelled Mead by Brewster) was a graduate of the United States Military Academy, but resigned shortly after graduation to become a civil engineer. At the time of the Mexican War, he re-entered the army and served in the capacity of military engineer. During the Civil War, he served with distinction at Second Bull Run, Antietam, and Fredericksburg. In the last two campaigns he commanded a division. At Chancellorsville he commanded a Corps and upon the relief of Hooker was given the reins of the Army of the Potomac. Two days later he met and defeated Lee at Gettysburg. It is to the misfortune of his memory that he did not follow up the victory by pursuit. From this point on, he "commanded" the Army of the Potomac, but Grant actually directed the action. Boatner, p. 539.

${ }^{41}$ Although born in Maryland, William Vandever moved to Iowa and became a Republican Congressman from that state. He commanded the Ninth Iowa as a Colonel in 1861, but by November 29, 1862 he became a Brigadier General in the U.S. Volunteers. He was to command several divisions, and he participated in actions at Pea Ridge, Vicksburg, and Bentonville. At the war's conclusion, he was breveted to Major General in the U.S. Volunteers. Boatner, pp. 866-67. 
the rebel works and taking charge of their arms. We have in the neighborhood of 30.000 prisoners including $1 \mathrm{Lt}$. General, 5 Major Genls and about nine Brigadiers an immense amount of ordnance etc. I have been through our part of their works but as yet have had no time to go into the City. We move our head quarters into the Town tomorrow at five AM. I am still very busy tonight and must close this hurriedly. Will write full particulars in my next. The talk this PM is to send our Division down to Port Hudson ${ }^{42}$ to help Bānks and I think we shall go. at any rate this will be decided within 48 hours. I must close now with all messages of love for you and every kind remembrance to all the family. you can imagine the excitement over our success but you can not realize the work we have to hurry through-believe me, as ever, my dear Wife ever affectionately yours, Jacob

\section{Works Consulted}

Boatner, Mark Mayo, III. The Civil War Dictionary. New York: David McKay Company, Inc., 1959.

Dyer, Frederick Henry. A Compendium of the War of the Rebellion. 3 volumes. New York: Thomas Yoseloff, 1959.

Grant, Ulysses S. Personal Memoirs of U. S. Grant. 2 volumes. New York: Charles L. Webster, 1886.

Ingersoll, Luston D. Iowa and the Rebellion: A History of the Troops Furnished by the State of Iowa to the Volunteer Armies of the Union, which Conquered the Great Southern Rebellion of 1861-5. Philadelphia: J. B. Lippincott and Company, 1866.

Johnston, Joseph E. Narrative of Military Operations. New York: D. Appleton and Company, 1874.

Livermore, Thomas L. Numbers and Losses in the Civil War in America: 1816-65. Bloomington: Indiana University Press, 1957.

Morrison, John H. History of American Steam Navigation. New York: Stephen Daye Press, 1958.

The War of the Rebellion: A Compilation of the Official Records of the Union and Confederate Armies. 128 volumes. Washington: Government Printing Office, 1880-1901.

${ }^{42}$ Port Hudson in Louisiana was a Confederate defense on the Mississippi which protected the area to the north of Baton Rouge. Earlier Admiral Farragut had hit it, but to little detriment of the defenders. A series of unsuccessful assaults followed, but finally on July 9,1863 , five days after the fall of Vicksburg, the place surrendered. Boatner, p. 663. 
Copyright of Annals of Iowa is the property of State of Iowa, by \& through the State Historical Society of Iowa and its content may not be copied or emailed to multiple sites or posted to a listserv without the copyright holder's express written permission. However, users may print, download, or email articles for individual use. 